\title{
UNITED IN DIVERSITY: CULTURAL AND COGNITIVE GROUNDS FOR WIDESPREAD PHRASEOLOGISMS
}

\author{
Kozlova T. O.
}

\section{INTRODUCTION}

Phraseologisms, most colourful and expressive lexical units, have been thoroughly studied since the introduction of the term phraseology by a prominent Swiss scholar Ch. Bally at the early twentieth century. An excellent exploration of structural, semantic and functional types of set expressions was provided by A. Kunin, Ye. Polivanov, V. Vinogradov, and later extended by I. Mel'chuk ${ }^{1}$. Their works remain a valuable theoretical source for well-established and new scientists. The interest in various aspects of phraseology ${ }^{2}$ is still growing and demonstrating a shift to multidisciplinary perspective: anthropological ${ }^{3}$, crosslinguistic ${ }^{4}$, cognitive ${ }^{5}$, and pragmatic-discursive ${ }^{6}$ approaches.

It seems that there is a consensus among modern scientists about the notion of phraseology as a wide range of multi-component, structurally stable and semantically indivisible figurative expressions that transfer important cultural concepts from generation to generation. That is why a number of

${ }^{1}$ Mel'chuk I. Phraseology in the language, in the dictionary, and in the computer. Yearbook of Phraseology. 2012. Issue 3. P. 31-56.

2 Phraseology: An Interdisciplinary Perspective. Granger S., Meunier, F. (Eds.). Amsterdam, Philadelphia : John Benjamins Publishing Co, 2008. 422 p.

${ }^{3}$ Telia V., Bragina N., Oparina E., Sandomirskaya I. Phraseology as a language of culture: Its role in the reproduction of cultural mentality. Phraseology: Theory, Analysis and Applications. Cowie A. P. (Ed.). Oxford : Oxford University Press, 1998. P. 55-75. Каліта І., Сівіцкая Н., Ляшчынская В. Беларуская мова ў люстэрку традыцый і інавацый. Пад аг. рэд. І. Каліты, Л. Яўдошынай). Ústí nad Labem: Univerzita J. E. Purkyně v Ústí nad Labem, 2019. 118 c.

${ }^{4}$ Piirainen E. "Widespread idioms in Europe and beyond". New insights into figurative language. Linguo-Cultural Research on Phraseology. 2015. Issue 3. P. 17-36. Vrbinc A., Vrbinc M. Phraseological units with onomastic components: The case of English and Slovene. RLA. Revista de lingüística teórica y aplicada. 2014. Issue 52. P. 133-153.

${ }^{5}$ Langlotz A. Idiomatic creativity: a cognitive-linguistic model of idiom-representation and idiom-variation in English. Amsterdam, Philadelphia : John Benjamins Publishing, 2006. 325 p.

${ }^{6}$ Árbol E. V. English versus Spanish Procedural Law Terminology and Phraseology: Troublesome Features for Translators. Lebende Sprachen. 2019. Issue 64 (1). P. 191-192. GoźdźRoszkowski S., Pontrandolfo G. Phraseology in legal and institutional settings: a corpus-based interdisciplinary perspective. New York : Routledge, 2017. 280 p. Jørgensen A. M., Moreno I. O. Phraseology in teenage language in Spanish, English and Norwegian: Notes on a number of fixed expressions that articulate disagreement. Languages in Contrast. 2019. Issue. 20 (1). P. 1-21. URL: https://www.researchgate.net/publication/330204333 (retrieved April 15, 2019). 
studies $^{7}$ on cultural phenomena manifestation in phraseological units pointed out the significance of pre-scientific beliefs and interpretations of the world, shared cultural practices and symbols in formation of phrasemes, as well as their literal and figurative readings. Attempts to look into the rich imagery implied in idioms unveiled cultural values and dominant conceptual metaphors motivating lexical means involved into linguistic construing of the world. In this respect, see a number of cross-linguistic studies on the idioms of emotion, particularly, 'anger' in Hindi ${ }^{8}$, Tunisian Arabic ${ }^{9}$, English and Japanese ${ }^{10}$. Apart from emotions, other popular target domains, which manifest in phraseology, include 'gender' ${ }^{11}$, 'home and family', 'God', 'truth', 'danger', 'death', 'stupidity', to name but a few ${ }^{12}$. The findings of numerous cross-cultural studies in the field of phraseology suggest that such lexico-semantic fields as 'body parts' and 'colours' are most productive source domains due to the fact that metaphoric thinking is basically grounded in embodied, perceptive experience.

The discussion of linguistic representations of conceptualised sociocultural dominants in various languages revealed both differences and similarities in phraseology, and contributed to the widespread phraseology issues. Having analyzed the inventory of idioms in genetically related and nonrelated languages, E. Piirainen ${ }^{13}$ discovered the common core of figurative lexical units, explored its origins, various sources as well as wide geographical distribution. As the research was continued ${ }^{14}$, the findings about 280 lexically and semantically similar idioms in more than 80 European and non-European languages demonstrated the role of social contacts, intercultural exchange, and intertextuality.

${ }^{7}$ Idioms: Processing, Structure and Interpretation. Cacciari Ch., Tabossi P. (Eds.). New York: Psychology Press, 2014. 360 p. Fotovatnia Z., Goudarzi M. Idiom comprehension in English as a foreign language: analyzability in focus. Procedia - Social and Behavioral Sciences. 2014. Issue 98. P. 499-503.

${ }^{8}$ Sharma S. Metaphor and emotion: A case of anger in Hindi phraseology. Cognitive Linguistic Studies. 2018. No 5 (2). P. 303-340.

${ }^{9}$ Maalej Z. Figurative language in anger expressions in Tunisian Arabic: An extended view of embodiment. Metaphor and Symbol. 2004. Issue 19 (1). P. 51-75.

${ }^{10}$ Ishida P. Contrastive idiom analysis. The case of Japanese and English idioms of anger. Phraseology: An Interdisciplinary Perspective. Granger S., Meunier F. (Eds.). Amsterdam, Philadelphia : John Benjamins Publishing Co., 2008. P. 275-292.

${ }^{11}$ Baran A. Gender in Estonian older phraseology. Linguo-Cultural Research on Phraseology. 2016. Issue 3. P. 315-335.

${ }^{12}$ Phraseology: An Interdisciplinary Perspective. Granger S., Meunier, F. (Eds.). Amsterdam, Philadelphia : John Benjamins Publishing Co, 2008. P. 162-172, 211-223.

${ }^{13}$ Piirainen E. Widespread idioms in Europe and beyond: toward a lexicon of common figurative units. Frankfurt a.M. : Peter Lang, 2012. 591 p.

${ }^{14}$ Piirainen E., Balazsi J. A. Lexicon of common figurative units: widespread idioms in Europe and beyond. Frankfurt a.M. : Peter Lang, 2016. 778 p. 
Despite new insights into the chronological layers, cultural and linguistic similarities in idiomatic expressions of numerous languages, the causes and mechanisms of idiomatic spread remain only partly disclosed. More research is also needed into the cognitive grounds of widespread idioms. Another important issue today is their internal and external dissemination. Not much focus has been given to the common genetic source and its phraseological continuants in cognate languages.

The purpose of this study was to ascertain cultural and cognitive factors causing lexical and semantic parallelism in idiomatic expressions of geographically distant languages. A second goal was to distinguish between external (across different languages) and internal (across different varieties of one language) idiomatic dispersion.

It is argued that many widespread idioms can be attributed to some universal strategies of construing the world. Cognitive patterns that emerge from life experience form the basis for similarity in cultural encoding. Many idiomatic manifestations in various languages show structural and semantic congruence in parallel with cultural specificity. Both cognitive universals and cultural differences among linguistic sign makers find their ways in metaphoric set expressions appearing united in diversity.

\section{Terminology and material employed in the study of widespread phraseologisms}

Traditionally, the terms figurative unit, phraseological unit, praseologism, phraseme, phrasal lexeme, word-combination, idiom, idiomatic phrase, set expression, and set phrase have been used to describe polylexical units with the features of structural stability and semantic indivisibility. Hence 'phraseology' becomes an umbrella term to include various types of language units with different degrees of invariability and idiomaticity, i.e. being metaphoric. Following this tradition, we employ the terms idiom, phraseologism and phraseological unit synonymously in this study.

As being metaphoric, indivisible and invariable are rather general features, the units under analysis fall into different categories: (a) completely fixed expressions and those that are found both in literal and figurative contexts (E. to have rats in the attic meaning literally "to live in a house with an attic infested with rats" and figuratively "to have strange ideas, be slightly mad"); (b) completely rigid and variable structures ((as) hungry as a hunter, wolf, rear "very hungry"); (c) multicomponent phrases and full sentences.

For the clarity and efficiency of the research procedure, the selection of units is limited to phrases. Proverbs, sayings, aphorisms, and other eloquent statements were not analysed here as they are longer structures expressing a complete thought, stating and handing down common truth, or giving advice. 
Another type of phraseology not considered here was syntactical phraseologisms. Even though they are expressions with fixed word order and somewhat weakened literal meanings, they are rather stereotyped syntactic deviations with variable components. The third group of expressions, which was not given due attention here, included occasionally or rarely and only recently used calques. It should be emphasised that such incorporations are speech-conscious phenomena, i.e. they are a matter of speakers' individual preferences and do not necessarily acquire systemic features.

For this study, 20 phraseological and general dictionaries were used to select idioms with structural and semantic similarities in several cognate and non-cognate languages, or in at least two geographically distant varieties of the pluricentric English. The selection was followed by a structural, contextual and conceptual analyses of idioms. As the study was not aimed at the exhaustive analysis or registration of idiomatic congruences in numerous languages, the contrastive analysis was carried out for a limited number of 50 English phraseologisms with structural and semantic parallels in other languages and varieties of English.

\section{Factors of cross-linguistic congruence in phraseology}

Languages differ immensely in phraseological word-stock. Idiomatic specificity is conditioned by numerous factors: cultural, occupational, or everyday practices (E. twiddle on thumbs lit. 'move smth repeatedly between your fingers, i.e. do smth without any purpose' hence "loaf”), social and historical situations (E. live like a lord, Fr. se la faire grasse "to have a luxurious way of life"), observations and popular beliefs about nature, human life and behaviour (Jap. hara ga tatsu 'lit. one's belly rises up, ${ }^{15}$, E. see red "be very angry"), etc.

Standing on the way of linguistic interchange, cultural specificity is in opposition to the factors encouraging internationalisation. In spite of tremendous differences, idiomatic layers in various languages have much in common. According to the recent research ${ }^{16}$, cross-linguistic idiomatic congruence seems to be mainly contact-induced. The translations of the Bible, literature popularity, intertextuality, and the global influence of English are

${ }^{15}$ Ishida P. Contrastive idiom analysis. The case of Japanese and English idioms of anger. Phraseology: An Interdisciplinary Perspective. Granger S., Meunier F. (Eds.). Amsterdam, Philadelphia : John Benjamins Publishing Co., 2008. P. 275-276.

${ }^{16}$ Piirainen E. Widespread idioms in Europe and beyond: toward a lexicon of common figurative units. Frankfurt a.M. : Peter Lang, 2012. 591 p. Piirainen E., Balazsi J. A. Lexicon of common figurative units: widespread idioms in Europe and beyond. Frankfurt a.M. : Peter Lang, 2016. 778 p. 
among powerful factors specified by E. Piirainen ${ }^{17}$. There may, however, be other noticeable reasons than culture contacts.

Consider such musical phraseologisms as E. have a face made of a fiddle "be irresistibly attractive", have face as long as fiddle "look depressed", be (as) fit as a fiddle "be healthy and strong" (originally "suitable for purpose"), etc. In spite of their half-century history, global influence of English, and transparent motivation (violinists' affectionate reference to the instrument ${ }^{18}$, associated resemblance between the shape and someone's face always wreathed in smiles ${ }^{19}$, the sound produced and a sad-looking expression of somebody's face), these expressions have been confined to the English-speaking community. In contrast, E. play second fiddle "take subordinate position", derived in the nineteenth century from a supportive role of Second Violin within an orchestra, has found its way in over 20 Indo-European languages, including Slavonic (Ru. играть вторую скрипку, Ukr. грати другу скрипку, Pol. grać drugie skrzypce), Baltic (Lith. griežti antruoju smuiku), Germanic (Afrk. speel tweede viol, Ger. die zweite Geige spielen, Sw. spela andra fiol, Norw. spille andrefiolin), Romance (Fr. jouer les seconds violons, Sp. desempeñar un papel secundario, Port. em segundo plano), Greek ( $\pi \alpha i \xi \xi \varepsilon l \delta \varepsilon v i \varepsilon \rho o ~ \beta i o \lambda l)$ and some Indo-Iranian languages. The idiom is also found in Turkic (Turk. ikinci derecede rol oynamak ${ }^{20}$ ), Dravidian, Austroasiatic, Afro-Asiatic, Austronesian, Sino-Tibetian, Koreanic (Korean), and isolate (Japanese) languages.

In addition to cross-linguistic similarity, phraseological units demonstrate language-internal parallelism due to the independent development of national varieties in pluricentric systems such as English. Numerous cases of phraseological congruence are found in the mainland and overseas Englishes. The latter obviously followed well-established, or normative, models to reinterpret popular perceptions and create their own, so to speak, new homegrown, phraseological expressions. Substitution with autochthonous borrowings and regionalisms proved to be the most employed strategy to produce culturally distinct, yet intelligible for speakers of other varieties phrases. Among particularly noticeable phraseologisms are those projecting local natural and cultural phenomena. For instance, general English (as) poor as a mouse "very poor" is continued in AusE as poor as a bandicoot (rat) including the name of

${ }^{17}$ Piirainen E. "Widespread idioms in Europe and beyond”. New insights into figurative language. Linguo-Cultural Research on Phraseology. 2015. Issue 3. P. 17-36.

${ }^{18}$ Barber K. Six Words You Never Knew Had Something to Do with Pigs: And Other Fascinating Facts About the English Language. Toronto : Oxford University Press, Canada; Penguin Books, 2007. 240 p.

${ }^{19}$ Dolgopolov Yu. A Dictionary of Confusable Phrases: More Than 10,000 Idioms and Collocations. Jefferson, North Carolina, London : McFarland \& Co, Inc., Publishers, 2016. P. 162.

20 Akdikmen R., Uzbay E. Pocket Turkish Dictionary. New York, Berlin, etc. : Langenscheidt, 2006. P. 368. 
an Australian marsupial popularly associated with deprivation and isolation ${ }^{21}$. AE within earshort "within reach, near" appears in AusE and NZE as within a coo-ee, where coo-ee is a borrowing from Dharuk, an Australian Aboriginal language ${ }^{22}$. NZE Maori $P T$ and its counterpart white man's $P T^{23}$, combining attributively used stems with the abbreviation of physical training to mean "resting, loafing", are known elsewhere as Egyptian PT.

The transference of a phraseological unit from one variety to another can result in its reinterpretation and hence opaque similarity. The phrase up a tree "entrapped; in a fix; in a difficult situation; cornered" ${ }^{24}$ was coined in the USA and gained currency in British English. It entered Australian English in the similar sense but with modified and extended shape possum up a gumtree (possum "an arboreal marsupial in Australia”, gumtree "an Australian species of eucalyptus") when it was brought in the second half of the nineteenth century by the forty-niners who left California in search of more luck on the mining gold-fields of Australia. Being used allusively as an expression of approbation ${ }^{25}$ in AusE, the idiom possum up a gumtree "in great difficulties" was soon given a different interpretation - up a gum tree "in another place, another state of mind; 'treed', cornered; in a state of confusion; in a predicament” ${ }^{\text {26 }}$. It appears amazing how similar metaphoric images can produce variant associations leading to different readings of similar expressions by speakers of the same language. More instances of phraseological similarity in different Englishes are discussed in Part 4.

It can be stated with certainty that apart from cultural influence and transparency of motivation, other factors appear crucial for the formation of widespread phraseology.

\section{Heteroglossia and pragmatic relevance of multiple borrowing}

Due to language and culture contacts, a number of expressions entered various languages as metaphorically extended calques. Those that overlap structurally and semantically across languages come into three subgroups which primarily deal with identifiable sources and popular beliefs. Most pivotal ones include:

${ }^{21}$ The Concise Australian National Dictionary. Hughes J. (Ed.). Oxford, Melbourne: Oxford University Press, 1992. P. 26.

${ }^{22}$ Ibid. P. 135.

${ }^{23}$ The Dictionary of New Zealand English. A Dictionary of New Zealandisms on Historical Principles. Orsman H. W. (Ed.). Auckland : Oxford University Press, 1997. P. 480.

${ }^{24}$ The New Oxford American Dictionary. Jewell E. J., Abate F. (Eds.). Oxford : Oxford University Press, 2001. P.1803.

${ }_{25}$ The Concise Australian National Dictionary. Hughes J. (Ed.). Oxford, Melbourne: Oxford University Press, 1992. P. 425.

${ }^{26}$ Ibid. P. 247. 
- phraseologisms traced back to literature, folklore, historical scenarios and witty quotes, such as cross the Rubicon "make an irreversible decision with consequences" found in 18 languages of the Indo-European (Germanic, Romance, Slavonic, Greek languages), Uralic (Finnish), Turkic (Kyrgyz), and Sino-Tibetan (Chinese) families;

- phraseologisms with religious and mythological account, for example, Augean stables "smth marked by corruption" which refers to the myth of Augeas, the king of Elis, and Hercules, and is used Indo-European, Uralic (Finnish, Estonian, Hungarian), Turkic (Kazakh), Noah's ark "a wide assortment of people or objects” referring to the Genesis flood narrative that found repeated variations in the Bible, the Quaran, and even older Mesopotamian stories, apple of discord implying "the core of a quarrel that can lead to a serious argument” used in 30 languages;

- contemporary life essential attributes and cultural symbols borrowed from international English, for instance, be on the same wavelength "share ideas and opinions" (from the notion of frequency in broadcast transmission) attested in 28 languages in Europe and beyond" ${ }^{27}$ slip on a banana skin "fail in a silly, embarrassing way" found in 27 languages ${ }^{28}$;

- phraseologisms based on popular beliefs and observations such as the calm before the storm used in 53 Indo-European and other language families ${ }^{29}$; crocodile tears "pretended show of sorrow" has manifested in Indo-European (Slavonic, Baltic, Germanic, Iranian, Armenian, Greek, Albanian languages), Dravidian (Telugu), Semitic (Arabic, Hebrew), Koreanic (Korean), SinoTibetan (Chinese) families due to an old belief that crocodiles wept when eating what they had caught.

Even though such phraseologisms may sound outdated (E. (old-fash.) cross the Rubicon, pass $\sim$ ), they are communicatively valuable. The internationalisation of such phrases is accompanied by heteroglossia. Not only do the speakers develop a kind of liking for particular expressions for cultural reasons, they tend to build up cultural continuity through the discursive copresence of the idioms related to particular historical periods, outstanding personalities, significant events, etc. Apart from their cultural value, these expressions carry out important pragmatic functions, help to anchor certain topics to various discourses. Multidiscursivity of multiple borrowings is determined by a set of pragmatic functions.

${ }^{27}$ Piirainen E. Europeanism, internationalism or something else? Proposal for a crosslinguistic and cross-cultural research project on widespread idioms in Europe and beyond. Hermes. Journal of Linguistics. 2005. Issue 35. P. 65-66.

${ }^{28}$ Piirainen E. "Widespread idioms in Europe and beyond". New insights into figurative language. Linguo-Cultural Research on Phraseology. 2015. Issue 3. P. 26.

${ }^{29}$ Ibid. P. 21. 
In mass-media and political discourses, allusions to important historical events of the distant past add expressivity to the utterances, produce rhetorical and suggestive effects in contemporary audience. For instance, the phrase cross the Rubicon: Turk. "Rubicon'u geçmek? onuncu yilinda avrupa komşuluk politikasi" 30 - "Crossing the Rubicon? European neighbourhood policy for a decade"; "Manila, Philippines - Philippine President Rodrigo Duterte said Monday he has decided to "cross the Rubicon" in his ties with the United States and will open trade alliances and offer long-term land leases to "the other side of the ideological barrier," China and Russia"31. In the given contexts, the informative function of the expression is pushed in the background by its pragmatic role of focusing on the life changing significance of the political decisions, and symbolising 'a point of no return, or a great change'.

Biblical or mythological allusions also undergo metaphoric extensions of the prototypes to be used figuratively in historical discourse, everyday communication, etc. For example, manna from heaven (found in 11 languages) refers to the episode from Exodus (16:15) when food was found by the Israelites on their journey out of Egypt. It is successfully employed in modern stories outside religious discourse: E. "Whilst navvies are earning 6s. or 7s. a day by making a railway I can understand that the trade should go on. The wages of the men fall into the little town like manna from heaven. But such a fall of manna as that is apt to come to a speedy end..." 32 ; Pol. "A to głód córko! A przynajmniej mleka / Kropelkę dajcie, wszak tu manna z nieba / Padać nie będzie dla biednej staruszki..." (Akt 4, Scena I) ${ }^{33}$ - "That is starving, my daughter! Could you give me some milk / Just a drop, there will be no manna from heaven for the poor old lady”; Pol. "Wygrana w lotto byla dla mnie jak manna z nieba. - "My winning the lottery was like manna from heaven.", "Wszystko ci przychodzi tak łatwo jak manna z nieba." - "He’s got it all easy like manna from heaven.", "Nie czekaj na manne z nieba a zrób coś sam." - "Don't wait for manna from heaven, do something yourself.” (T. Babij, S. Kucharczuk, I. Jurga - from personal communication); Bulg. "Какво правиш тука? Чакаш? - Чакам мана небесна." (O. Stryzhkova - from personal communication) - "What are you doing? Waiting? - Waiting for manna from heaven". In the historical accounts of the New World, the idiom provides the economy of narration and reveals the

${ }^{30}$ Yazgan H. Rubicon'u geçmek? onuncu yilinda avrupa komşuluk politikasi. Uluslararası Hukuk ve Politika. 2014. Issue 42. URL: https://www.ceeol.com/search/article-detail?id=284401 (retrieved May 05, 2019). P. 103.

31 Cerojano T. Philippines' Rodrigo Duterte about to 'cross the Rubicon' with US. The Associated Press. Global News. September 26, 2016. URL: https://globalnews.ca/news/ 2964595/philippines-rodrigo-duterte-about-to-cross-the-rubicon-with-us/ (retrieved April 26, 2019).

${ }^{32}$ Trolloppe A. Australia and New Zealand. Cambridge : Cambridge University Press, 2013. P. 385.

${ }^{33}$ Słowacki J. Balladyna. Białobrzegi : Klasyka na Ebookah. Masterlab, 2015. 
relief from hardships of early settlers' life in the colony. In everyday communication, it realizes hyperbolisation, and intensifies the intended influence of the sign on the addressee.

\section{Cognitive grounds of polygenesis in phraseology}

The appearance of structurally and semantically similar phraseologisms across languages can be attributed to their independent development in various systems. The process of polygenesis is rooted in the universal aspects of human cognition, perception, shared strategies of encoding the acquired experience and construing the worldview.

Observations of natural environment, animal and human behaviour result in similar idiomatic expressions. For instance, the beneficial effect of rain on plants seen in the acceleration of their growth have motivated congruence in the idioms meaning "abundance”: E. spring up like mushrooms after rain, pop up , Sw. växa upp som svampar ur marken "lit. spring up like mushrooms out of the ground”, Pol. wyrastać (mпоżyć się) jak grzyby po deszczu, Rus. появляться, как грибы после дождя, Ch. уuhou-chunsun "spring up like bamboo shoots after rain" ${ }^{34}$, and Jap. ugo no takenoko "bamboo shoots after rain" 35.

Experiencing and recognizing physiological signs of emotions may result in similar conceptualizations. Consider the state of mental violence in a situation of fury that causes the cross-cultural image of something filled with air, liquid, steam to blow up, or lift the top off: E. blow one's top "be very angry", Du. "De stoom komt uit zijn oren." - "The steam is coming out of his

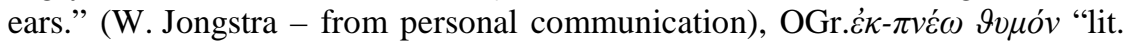
breath out steam, incense smoke", L. animo concipere iras, Jap. hara ga tatsu "lit. one's belly rises up", Kor. ttukkong yolli-nda "lit. my lid is opening" 36 . The behavioural expression of such a negative emotion as anger also fits into the "hydraulic" model encoded as outward swelling, boiling, upward movement in Slavonic (Polish), Semitic (Hebrew, Tunisian Arabic), Polynesian (Toraja), Niger-Congo Bantu (Zulu) languages ${ }^{37}$. To give a few other examples, gasping or not breathing as the end-of-life signs stimulated similar cross-linguistic expressions meaning "to die” derived from 'to give / breath out soul, life away'

${ }^{34}$ Huilin S. Does it have to be cheap, kitsch, and Western?: A critical analysis of the development of graphic design in China. Contemporary Chinese Visual Culture. tradition, Modernity, and Globalization. Crouch Ch. (Ed.). Amherst, New York : Cambria Press, 2010. P. 376.

${ }^{35}$ Hartley J. TV stories: from representation to productivity. Story Circle: Digital Storytelling Around the World. Hartley J., McWilliam K. (Eds.). Malden : Wiley-Blackwell, 2009. P. 31.

${ }^{36}$ Park D.-S. Slang in Korean. Korean Language in Culture and Society. Sohn H.-M. (Ed.). Honolulu: University of Hawai'i Press, 2006. P. 122.

${ }^{37}$ Lockett L. Anglo-Saxon Psychologies in the Vernacular and Latin Traditions. Totonto : University of Toronto Press, 2011. P. 155-157. 
in Turk. can vermek ${ }^{38}$, Ru. ucnycmumb dyx, Pol. wyzionać ducha, E. give up the ghost, Ger. den Geist aufgeben / seinen Geist aushauchen /den Löffel abgeben,

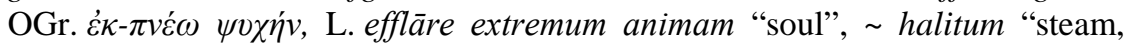
breathing", spiritum "spirit". The analogous forms and meanings in the above-mentioned instances stem from the universal strategies of conceptualization.

The theory of polygenesis is also applicable to comparative idioms. Similar expressions have originated independently in numerous languages to express disapproval of extreme thinness in people. Cf. E. as thin / skinny as a board, $\sim$ lath, $\sim$ nail, $\sim$ rail, $\sim$ rake, $\sim$ skeleton, $\sim$ stick, $\sim$ thread, $\sim$ toothpick, whipping post, $\sim$ whippet, wisp, Ger. dünn wie ein Bleistift "pencil", Latte "lath", Streichholz "match", Du. zo mager als een lat "bar", Fr. maige commme un clou "nail”, Sp. hecho un fideo "macaroni”, Rus. худой / тощий, как щепка "chip", спичка "match", жердь "pole”, Ukr. худий як скіпка "chip”, тріска "chip", Pol. chudy jak patyk "rod, bar", szczapa "chip", szkielet "skeleton”, Cz. vyzáblý jako kostlivec "skeleton”, louč "chip, rushlight”, souška "a piece of dry wood”, tyčka "rod, pole”, Turk. degnek gibi zayif "lit. (as) rod as thin", and Ch. jian zui hou sai "as thin as a monkey" ${ }^{39}$. An incredibly thin, anorexic body is cross-culturally conceptualised as 'a long thin object'.

In the above cases, the linguistic convergence may be linked to human psychological reality. One and the same structuring principle, or "idealized cognitive model" ${ }^{40}$ is neutrally grounded and occurs in languages as a result of a conceptual abstracting from the perceived differences in similar cases. As the studies suggest, knowledge about thinness "includes a long, thin object schema" ${ }^{41}$, and anger is conceptualised through the image schema of hot liquid in a container ${ }^{42}$. This makes clear that schemas are visual gestalts that "emerge as meaningful structures for us chiefly at the level of our bodily movements through space, our manipulations of objects, and our perceptual interactions” ${ }^{\text {43 }}$. Being recurrent patterns and regularities, image schemas are neither confined to a single perceptual modality nor to an individual cognitive experience. Rather,

${ }^{38}$ Jacobson J. S. Turkish Folk Reader. Salt Lake City : University of Utah Printing Press, 1967. P. 20, 170.

${ }^{39}$ Young X. Cultural comparisons of English and Chinese idioms. In F. Zheng (Ed.), Biotechnology, Agriculture, Environment and Energy. London : \& Taylor \& Francis Group, 2015. P. 197.

${ }^{40}$ Lakoff G. Women, fire, and dangerous things: What categories reveal about the mind. Chicago : University of Chicago Press, 1987. P. 68-76.

${ }^{41}$ Ibid. P. 105-108, 114.

${ }^{42}$ Lakoff G., Kövecses Z. The cognitive model of anger inherent in American English. Cultural Models in Language and Thought. Holland D., Quinn N. (Eds.). New York \& Cambridge : Cambridge University Press, 1987. P. 195-221.

${ }_{43}$ Johnson M. The Body in the Mind: The Bodily Basis of Meaning, Imagination, and Reason. Chicago : University of Chicago Press, 1987. P. 29. 
they are an essential part of collective cultural experience. Viewed from this perspective, idealized models are interpreted as condensed and dynamic (i.e. transformable) conceptual analogues of spacial operations ${ }^{44}$ through which human beings represent the world and themselves. In addition to that, image schemas are seen as the wholes consisting of components "standing in simple relations" ${ }^{45}$.

It is the image-schematic plasticity combined with human creativity and cognitive selectivity that enable open variation in idioms. For instance, incredible thinness in humans is conceptualized as a small distance between two opposite sides of an entity in terms of the stretching, straight up model (see the examples above), or alternatively, in terms of the monolayer model appealing to names of flat covers or materials: E. as thin as paper, $\sim$ a shadow, $\sim$ skin, $\sim a$ soap bubble, Ger. dünn wie ein Blatt ("leaf”), Cz. vyzáblý jako stín (“shadow”). The cognitive and pragmatic preferences determine the choice between vertical and horizontal projections.

Patterns of linguistic and cultural experience would work in a similar way for the variant interpretations of eccentricity. To emphasise mental and behavioural deviations, the associations are established between entities conceptualised as containers: a human head "the upper part of the body containing the brain” and an enclosure, a person's nonsensical manner or behaviour and an animal that becomes a nuisance or causes riot when disturbed. The preference for vertical model emerges as a linguistic structure incorporating a name for the top of a building (Fr. avoir une araignée au plafond "lit. have a spider on the ceiling", $\mathrm{BE}$ and $\mathrm{AE}$ have bats in the belfry, have rats in the attic, NZE have / get a rat in one's garret ${ }^{46}$ ), whereas an alternative possibility would adopt a horizontal perspective to the conceptualised experience. The latter would linguistically manifest owing to the associations with a type of container close to the ground (a plot, a fenced area, etc.) as in AusE have kangaroos in one's top paddock ${ }^{47}$.

Returning to the sources and causes of widespread phraseology, it should be pointed out that cognitive force plays a great role in the dissemination of phraseological expressions. Not only does it provide the independent development of similar idioms in various languages, but also enables formations by analogy in different, historically and geographically distant

${ }^{44}$ Johnson M. The Body in the Mind: The Bodily Basis of Meaning, Imagination, and Reason. Chicago : University of Chicago Press, 1987. P. 25.

${ }^{45}$ Ibid. P. 28.

${ }^{46}$ The Dictionary of New Zealand English. A Dictionary of New Zealandisms on Historical Principles. Orsman H. W. (Ed.). Auckland : Oxford University Press, 1997. P. 658.

${ }^{47}$ The Concise Australian National Dictionary. Hughes J. (Ed.). Oxford, Melbourne: Oxford University Press, 1992. P. 286. 
varieties of a single language. This statement can be well evidenced by the above examples of phraseologisms meaning "strange, eccentric" in English. Variation has been achieved in two ways: firstly, through the cognitive pattern propagation and its increasing reproduction in different sociocultural environments; secondly, through the perspectivisation, that is a form of conceptualisation developed on choosing a certain perspective of experience interpretation.

\section{Cognitive transparency and semiotic advantage}

The congruence of idioms can be attributed to cognitive economy and semiotic advantage. This is found in holistic expressions explicating the syncretism of worldview. One of them is E. day and night "all the time" that displays parallels in 50 languages of Europe, Asia, Africa, New Zealand ${ }^{48}$. We cannot do more but agree with E. Piirainen, who argues this case by polygenesis, yet does not go further stating that "bipolarity between darkness and brightness is already mentioned in the earliest writings ... [and] the conceptualization of the alternating daylight and dark as 'all the time' seems to have arisen spontaneously" 49 . The structure in question is of a very archaic origin that is likely to go back to the reconstructed proto-layer: PIE *dhgwhos \& nok $\left({ }^{w}\right) t$ - Its panchronicity is established through similarity with copulative complex structures and dvandva compounds which continue the PIE etymon in L. dies noctibus, Skr. naktám-dina, OIc. nótt ok dag, etc. to refer to "a particular period of time": OIc. fara dagfari ok náttfari "lit. travel during the day and during the night (dag-far "a day-fare journey") ${ }^{50}$; Ger. Tag und Nacht (as in Tag- und Nachtarbeit "a 24-hour work"). As follows from the ancient and modern contexts, such copulative construction is an iconic encoding of a syncretic sense 'when and how smth occurs'. It can be assumed that it has become relatively stable in the history of languages due to the cognitive economy, which is achieved through the semiotic advantage of using transparent encoding means and imitative naming strategy. That is how the notion is mirrored in language owing to the isomorphism between the encoding structure and its mental designatum, i.e. encoded experience ${ }^{51}$. More evidence can be retrieved from cross-linguistic investigation into idioms related to spacial

${ }^{48}$ Piirainen E. "Widespread idioms in Europe and beyond”. New insights into figurative language. Linguo-Cultural Research on Phraseology. 2015. Issue 3. P. 28-29.

${ }^{49}$ Ibid. P. 29.

${ }^{50}$ Cleasby R., Vigfusson G. An Icelandic-English Dictionary (1874). Germanic Lexicon Project. 2019. URL: http://lexicon.ff.cuni.cz/texts/oi_cleasbyvigfusson_about.html (retrieved May 04, 2019). P. 142.

${ }^{51}$ Givón T. Iconicity, isomorphism, and non-arbitrary coding in syntax. Iconicity in Syntax: Proceedings of a Symposium on Iconicity in Syntax, Stanford, June 24-6, 1983. Haiman J. (Ed.). Amsterdam : John Benjamins Publishing, 1985. P. 189. 
and temporal deixis ${ }^{52}$ demonstrating the regularity of such dichotomies as E. here and there, now and then; Du. hier en daar; Ukr. mym i maм; Pol. tu $i$ tam; Turk. tek tü ${ }^{53}$, Kor. yeogi jeogi $i^{54}$, etc. As is clear, continuity and repetitiveness are universally encoded by full and partial (ablaut) reduplications or copulative units leading to close parallels and precision of idiomaticity available cross-linguistically.

\section{CONCLUSIONS}

Quite a number of phraseologisms are widely spread across typologically, geographically and genetically close and distant languages. With the results of this study, the sources, causes, and paths of cross-linguistic similarity in idiomatic expressions can be better explained. It is important to distinguish between external and internal dissemination of idioms. Encouraged by contact-induced situations, the external spread is produced by (semi)calquing and internationalisation. Among multiple borrowings into different languages, units with Biblical, mythological, and historical allusions reign supreme to be inventively used in modern non-religious, non-mythological, etc. contexts. Internationalised through the repertoire of the global English, such expressions acquired multidiscursivity and pragmatic relevance, became an important part of the intercultural competence. Independent cross-language development of similar phraseology is enforced by cognitive factors: universality of perceptual and psychological activity, strive for encoding transparency and extrapolation of the acquired experience to cognise new phenomena, as well as the power of analogy. However, universal trend is accompanied by cultural specificity allowing cognitive plasticity and human creativity interact. Variability in widespread phraseology is enabled by a cognitive pattern propagation in various sociocultural environments, the choice of a perspective made by cognisers to discover new things, store, and retrieve information.

Further research investigating types and degrees of variability in the form, imagery and functions of widespread phraseologisms, could have positive implications in the fields of psycholinguistics, intercultural communication and language teaching. In cognitive and psycholinguistic experiments, participants may be interviewed for the transparency and recognizability of widespread phraseologisms to find out about their universality and role in figurative interpretation of the world, storage and processing information. It is also

${ }^{52}$ Here and There: Cross-Linguistic Studies on Deixis and Demonstration. Wissenborn J., Klein W. (Eds.). Amsterdam/Philadelphia : John Benjamins Publishing Co., 1982. 298 p.

${ }_{53}$ Turkish. Basic Course. Units 1-30. Swift L. B., Ağrali S. (Eds.). Washington D. C. : Foreign Service Institute, department of State, 1966. P. 425.

${ }^{54}$ Learn Korean. Level 2: Absolute beginner. Vol 3. Lessons 1-25. Innovative Language Learning. [e-Book]. 175 p. 
necessary to put cultural and linguistic competence at the center of intercultural communication studies and focus on culture and language awareness, mutual intelligibility and use of widespread phraseologisms in various spheres of communication. Further work in foreign language learning and teaching suggests itself in elaborating efficient approaches to formulaic expressions acquisition and production. Familiarising learners with cross-cultural images embedded in phraseology will allow them to explore universal cultural reference, compare and contrast it with their own culture. Relevant interactive approaches and up-to-date methods will stimulate multilingualism and multiculturalism, increase cultural tolerance by demonstrating that linguistic unity and diversity are two inseparable constituents of human civilisation.

\section{SUMMARY}

Typologically, genetically, and geographically distant languages reveal some congruence in the realm of phraseology. Despite new and insightful investigations into the historical, cultural, and cognitive aspects of set expressions, the issue of their similarity and worldwide spread requires further work. Such factors as language contacts, cultural interchange, intertextuality, independent development remain insufficient for understanding convergence trends in phraseological stocks among numerous languages. The purpose of this study is to look into phraseological parallelism from cultural and cognitive perspectives, and focuse on external (across languages) and internal (across English varieties) dissemination of phraseologisms. It is argued that it is necessary to distinguish between phraseology internationalization and widespreadness. Internationalisation is a result of multiple borrowing of idioms by calquing and semi-calquing, while widespreadness is a wider notion that also implies polygenesis through independent development and analogy. Phraseological dispersion can be attributed to some universal strategies of construing the world whereas internationalisation is enabled by pragmatic relevance of loans and leads to multudiscursivity of units in question. Parallel development of phraseologisms is due to universal features of human perception, cognition and psychological reality. Owing to the plasticity of image schemas and human creativity in applying acquired experience to cognise new things, similar idioms are open for variation and appear united in their diversity. 


\section{REFERENCES}

1. Каліта I., Сівіцкая Н., Ляшчынская В. Беларуская мова ў люстэрку традыцый і інавацый. Пад аг. рэд. І. Каліты, Л. Яўдошынай). Ústí nad Labem: Univerzita J. E. Purkyně v Ústí nad Labem, 2019. 118 c . doi: 10.21062/ujep/265.2019/k/978-80-7561-178-9.

2. Akdikmen R., Uzbay E. Pocket Turkish Dictionary. New York, Berlin, etc. : Langenscheidt, 2006. 624 p.

3. Árbol E. V. English versus Spanish Procedural Law Terminology and Phraseology: Troublesome Features for Translators. Lebende Sprachen. 2019. Issue 64 (1). P. 191-192. doi: 10.1515/les-2019-0012.

4. Baran A. Gender in Estonian older phraseology. Linguo-Cultural Research on Phraseology. 2016. Issue 3. P. 315-335.

5. Barber K. Six Words You Never Knew Had Something to Do with Pigs: And Other Fascinating Facts About the English Language. Toronto : Oxford University Press, Canada; Penguin Books, 2007. 240 p.

6. Cerojano T. Philippines' Rodrigo Duterte about to 'cross the Rubicon' with US. The Associated Press. Global News. September 26, 2016. URL: https://globalnews.ca/news/2964595/philippines-rodrigo-duterte-aboutto-cross-the-rubicon-with-us/ (retrieved April 26, 2019).

7. Cleasby R., Vigfusson G. An Icelandic-English Dictionary (1874). Germanic Lexicon Project. 2019. URL: http://lexicon.ff.cuni.cz/texts/oi_ cleasbyvigfusson_about.html (retrieved May 04, 2019).

8. Dolgopolov Yu. A Dictionary of Confusable Phrases: More Than 10,000 Idioms and Collocations. Jefferson, North Carolina, London : McFarland \& Co, Inc., Publishers, 2016. 403 p.

9. Fotovatnia Z., Goudarzi M. Idiom comprehension in English as a foreign language: analyzability in focus. Procedia - Social and Behavioral Sciences. 2014. Issue 98. P. 499-503. doi:10.1016/j.sbspro.2014.03.445

10. Givón T. Iconicity, isomorphism, and non-arbitrary coding in syntax. Iconicity in Syntax: Proceedings of a Symposium on Iconicity in Syntax, Stanford, June 24-6, 1983. Haiman J. (Ed.). Amsterdam : John Benjamins Publishing, 1985. P. 187-220.

11. Goźdź-Roszkowski S., Pontrandolfo G. Phraseology in legal and institutional settings: a corpus-based interdisciplinary perspective. New York : Routledge, 2017. 280 p.

12. Hartley J. TV stories: from representation to productivity. Story Circle: Digital Storytelling Around the World. Hartley J., McWilliam K. (Eds.). Malden : Wiley-Blackwell, 2009. P. 16-36.

13. Here and There: Cross-Linguistic Studies on Deixis and Demonstration. Wissenborn J., Klein W. (Eds.). Amsterdam / Philadelphia : John Benjamins Publishing Co., 1982. 298 p. 
14. Huilin S. Does it have to be cheap, kitsch, and Western?: A critical analysis of the development of graphic design in China. Contemporary Chinese Visual Culture. tradition, Modernity, and Globalization. Crouch Ch. (Ed.). Amherst, New York : Cambria Press, 2010. P. 359-390.

15. Idioms: Processing, Structure and Interpretation. Cacciari Ch., Tabossi P. (Eds.). New York: Psychology Press, 2014. 360 p.

16. Ishida P. Contrastive idiom analysis. The case of Japanese and English idioms of anger. Phraseology: An Interdisciplinary Perspective. Granger S., Meunier F. (Eds.). Amsterdam, Philadelphia : John Benjamins Publishing Co., 2008. P. 275-292.

17. Jacobson J. S. Turkish Folk Reader. Salt Lake City : University of Utah Printing Press, 1967. 187 p.

18. Johnson M. The Body in the Mind: The Bodily Basis of Meaning, Imagination, and Reason. Chicago : University of Chicago Press, 1987. 272 p.

19. Jørgensen A. M., Moreno I. O. Phraseology in teenage language in Spanish, English and Norwegian: Notes on a number of fixed expressions that articulate disagreement. Languages in Contrast. 2019. Issue. 20 (1). P. 1-21. URL: https://www.researchgate.net/publication/330204333 (retrieved April 15, 2019). doi: 10.1075/lic.17013.jor.

20. Lakoff G. Women, fire, and dangerous things: What categories reveal about the mind. Chicago : University of Chicago Press, 1987. 614 p.

21. Lakoff G., Kövecses Z. The cognitive model of anger inherent in American English. Cultural Models in Language and Thought. Holland D., Quinn N. (Eds.). New York \& Cambridge : Cambridge University Press, 1987. P. 195-221.

22. Langlotz A. Idiomatic creativity: a cognitive-linguistic model of idiom-representation and idiom-variation in English. Amsterdam, Philadelphia : John Benjamins Publishing, 2006. 325 p.

23. Learn Korean. Level 2: Absolute beginner. Vol 3. Lessons 1-25. Innovative Language Learning. [e-Book]. 175 p.

24. Lockett L. Anglo-Saxon Psychologies in the Vernacular and Latin Traditions. Totonto : University of Toronto Press, 2011. 495 p.

25. Maalej Z. Figurative language in anger expressions in Tunisian Arabic: An extended view of embodiment. Metaphor and Symbol. 2004. Issue 19 (1). P. 51-75. doi:10.1207/S15327868MS1901_3.

26. Mel'chuk I. Phraseology in the language, in the dictionary, and in the computer. Yearbook of Phraseology. 2012. Issue 3. P. 31-56. doi: 10.1515/phras-2012003.

27. Park D.-S. Slang in Korean. Korean Language in Culture and Society. Sohn H.-M. (Ed.). Honolulu: University of Hawai'i Press, 2006. P. 118-131. 
28. Phraseology: An Interdisciplinary Perspective. Granger S., Meunier, F. (Eds.). Amsterdam, Philadelphia : John Benjamins Publishing Co, 2008. 422 p.

29. Piirainen E. "Widespread idioms in Europe and beyond". New insights into figurative language. Linguo-Cultural Research on Phraseology. 2015. Issue 3. P. 17-36.

30. Piirainen E. Europeanism, internationalism or something else? Proposal for a cross-linguistic and cross-cultural research project on widespread idioms in Europe and beyond. Hermes. Journal of Linguistics. 2005. Issue 35. P. 45-75.

31. Piirainen E. Widespread idioms in Europe and beyond: toward a lexicon of common figurative units. Frankfurt a.M. : Peter Lang, 2012. 591 p.

32. Piirainen E., Balazsi J. A. Lexicon of common figurative units: widespread idioms in Europe and beyond. Frankfurt a.M. : Peter Lang, 2016. 778 p.

33. Sharma S. Metaphor and emotion: A case of anger in Hindi phraseology. Cognitive Linguistic Studies. 2018. No 5 (2). P. 303-340. doi: https://doi.org/10.1075/cogls.00023.sha.

34. Słowacki J. Balladyna. Białobrzegi : Klasyka na Ebookah. Masterlab, 2015. 95 p.

35. Telia V., Bragina N., Oparina E., Sandomirskaya I. Phraseology as a language of culture: Its role in the reproduction of cultural mentality. Phraseology: Theory, Analysis and Applications. Cowie A. P. (Ed.). Oxford : Oxford University Press, 1998. P. 55-75.

36. The Concise Australian National Dictionary. Hughes J. (Ed.). Oxford, Melbourne: Oxford University Press, 1992. 662 p.

37. The Dictionary of New Zealand English. A Dictionary of New Zealandisms on Historical Principles. Orsman H. W. (Ed.). Auckland : Oxford University Press, 1997. 965 p.

38. The New Oxford American Dictionary. Jewell E. J., Abate F. (Eds.). Oxford : Oxford University Press, 2001. 2023 p.

39. Trolloppe A. Australia and New Zealand. Cambridge : Cambridge University Press, 2013. 544 p.

40. Turkish. Basic Course. Units 1-30. Swift L. B., Ağrali S. (Eds.). Washington D. C. : Foreign Service Institute, department of State, 1966. 746 p.

41. Vrbinc A., Vrbinc M. Phraseological units with onomastic components: The case of English and Slovene. RLA. Revista de lingüística teórica y aplicada. 2014. Issue 52. P. 133-153. doi: 10.4067/S071848832014000100007.

42. Yazgan H. Rubicon'u geçmek? onuncu yilinda avrupa komşuluk politikasi. Uluslararası Hukuk ve Politika. 2014. Issue 42. P. 103-132. URL: https://www.ceeol.com/search/article-detail?id=284401 (retrieved May 05, 2019). 
43. Young X. Cultural comparisons of English and Chinese idioms. In F. Zheng (Ed.), Biotechnology, Agriculture, Environment and Energy. London : \& Taylor \& Francis Group, 2015. P. 195-198.

\section{ABBREVIATIONS AND SYMBOLS}

$\mathrm{AE}$ - American variety of English

Afrk. - Afrikaans

AusE - Australian variety of English

BE - British variety of English

Bulg. - Bulgarian

Ch. - Chinese

Cz. - Czech

Du. - Dutch

E. - English

Fr. - French

Ger. - German

Gr. - Greek

Jap. - Japanese

Kor. - Korean

L. - Latin

Lith. - Lithuanian
Norw. - Norwegian

NZE - New Zealand variety of English

old-fash. - old-fashioned

OGr. - Old Greek

OIc. - Old Icelandic

PIE - Proto-Indo-European

Pol. - Polish

Port. - Portuguese

Ru. - Russian

Skr. - Sanskrit

Sp. - Spanish

Sw. - Swedish

Turk. - Turkish

Ukr. - Ukrainian

* - reconstructed form

\section{ACKNOWLEDGEMENTS}

I would like to thank my friends and colleagues Wouter Jongstra (Netherlands), Tetyana Babij, Sylwek Kucharczuk, Iwona Jurga (Poland), Olga Stryzhkova (Bulgaria) for their help with collection and interpretation of Dutch, Polish, and Bulgarian phraseologisms.

\section{Information about the author:} Kozlova T. O., Doctor of Philological Sciences, Associate Professor, Professor at the English Department,

Zaporizhzhia National University 66, Zukovsky str., Zaporizhzhia, 69600, Ukraine 